\author{
V. Boychuk ${ }^{1}$, V. Kotsyubynsky ${ }^{1}$, K. Bandura ${ }^{2}$, M. Hodlevska ${ }^{1}$, \\ B. Dzundza ${ }^{1}$, O. Khatsevych ${ }^{1}$
}

\title{
The Mechanisms of Nickel-Iron Spinel Phase Nucleation in Aquous Solutions: Crystal Quasichemical Approach
}

\author{
${ }^{1}$ Vasyl Stefanyk Precarpathian National University, 76018 Ivano-Frankivsk, Ukraine, vmbojchuk@gmail.com \\ ${ }^{2}$ Ivano-Frankivsk National Medical University, 76018 Ivano-Frankivsk, Ukraine, banduracristina@gmail.com
}

\begin{abstract}
The phenomenological model of nikel-iron spinel nucleation with spinel structure based on the partial charge theory and analysis of hydrolysis and polycondensation processes at the interaction of $\mathrm{Fe}^{3+}-, \mathrm{Fe}^{2+}-$ and $\mathrm{Ni}^{2+}$ hydroxocomplexes at different $\mathrm{pH}$ values of reaction medium was proposed. UV-vis optical spectroscopy was used for verification of the obtained results about the regularities of hydroxocomplexes formation. Crystal quasichemistry approach was applied for nucleation of nikel-iron spinel under the conditions of predomination of different defect types in $\mathrm{Ni}_{x} \mathrm{Fe}_{3-x} \mathrm{O}_{4-\delta}$ ( $\delta$ is oxygen non-stoichiometry) spinel lattice. The analysis of changes in electrical conductivity and lattice parameter of defect nickel-iron spinel as a function of $\mathrm{Ni}^{2+}$ atomic concentration was done for different values of $\delta$ parameter.
\end{abstract}

Keywords: defect nickel-iron spinel, hydroxocomplex, lattice parameter, optical spectroscopy.

Стаття поступила до редакиії 02.06.2019; прийнята до друку 15.06.2019.

\section{Introduction}

Ultrafine ferrites with spinel structure are attractive materials due to interesting magnetic, electrical, catalityc and elelctrochemical properties. Nickel-iron spinel has attractive wide application field because of its fascinating electromagnetic characteristics which allow using of these materials as magnetic storage systems [1], catalysts [2], photocatalysts [3], materials with negative differential resistance [4], gas sensors [5], in drug delivery [6] as MRT imaging agent [7], electrode materials. The possibility of successful application of ferrite nanopowder is determined by the magnetic and electrical properties that depend on the crystal ordering and average particle size. There are several synthesis approach of ultrafine nickel spinel. Ceramic, sol-gel and self-combustion syntheses [8-10] are the most widespead ones. The conrtol and prognosis of crystal structure formation at a stage of oxide phase nucleation is an important task which allows obtaining of ultrafine spinel materials with complex predicted properties.

\section{I. $\mathrm{NiFe}_{2} \mathrm{O}_{4}$ spinel nucleation: protolysis and polycondensation}

The nucleation of the condensed phases from the solution of metal $(M)$ salts is based on the procesess of hydrolysis and polycondensation of metal hydrocomplexes and is described by the terms of nucleophilic substitution as:

$$
-\mathrm{M}-\mathrm{OR}+\mathrm{XOH} \rightarrow-\mathrm{M}-\mathrm{OX}+\mathrm{ROH},
$$

where $R$ is a radical, $X=H$ for protolysis and $X=M$ for condensation processes. Partial Charge Model (PCM) [11] allows decribing the hydrolization of metal ions and finding out the regularities of olation and oxolation interactions between hydrocomlpexes which determine the nuclaetion of new phases. The theory is based on the Sanderson principle of electronegativity equalization. The hydrolysis of metal ions in an aqueous medium involves the formation of $\left[\mathrm{M}\left(\mathrm{OH}_{2) \mathrm{N}}\right]^{\mathrm{z}+}\right.$ complexes, where $N$ is a coordination number (for transition metals the formation of octahedrally coordinated ionic complexes is typical, $N=6$ ), $\mathrm{z}$ is an oxidation degree. Iron chloride hydrolysis in acidic medium leads to the formation of chlorine-containing complexes $\left[\mathrm{Fe}^{(I I I)} \mathrm{Cl}\left(\mathrm{H}_{2} \mathrm{O}\right)_{5}\right]^{2+}$ and $\left[\mathrm{Fe}^{(I I I)} \mathrm{Cl}_{2}\left(\mathrm{H}_{2} \mathrm{O}\right)_{4}\right]^{+} \quad$ [12] but in diluted solutions $\left[\mathrm{Fe}\left(\mathrm{H}_{2} \mathrm{O}\right)_{6}\right]^{3+}$ and $\left[\mathrm{Fe}\left(\mathrm{H}_{2} \mathrm{O}\right)_{6}\right]^{2+}$ mononuclear complexes are predominant [13]. Redistribution of charges between the cation and the ligands occurs with the formation of $\sigma$ bonds of $\mathrm{M}-\mathrm{OH}_{2}$, which leads to the redistribution of the electron density from the binding $3 a_{l}$ molecular orbital of the coordinated water molecules to the unburned cation orbitals. As a result $\mathrm{O}-\mathrm{H}$ bond in the coordinated water molecules is weakened and the protolysis occures according to the scheme:

$$
\left[\mathrm{M}\left(\mathrm{OH}_{2}\right)_{N}\right]^{z+}+h \mathrm{H}_{2} \mathrm{O} \rightarrow\left[\mathrm{M}(\mathrm{OH})_{h}\left(\mathrm{OH}_{2}\right)_{\mathrm{N}-h}\right]^{(z-h)+}+h \mathrm{H}_{3} \mathrm{O}^{+} \text {. }
$$$$
\text { The electronegativity }\left(\chi_{p}\right) \text { of the obtained }
$$ 


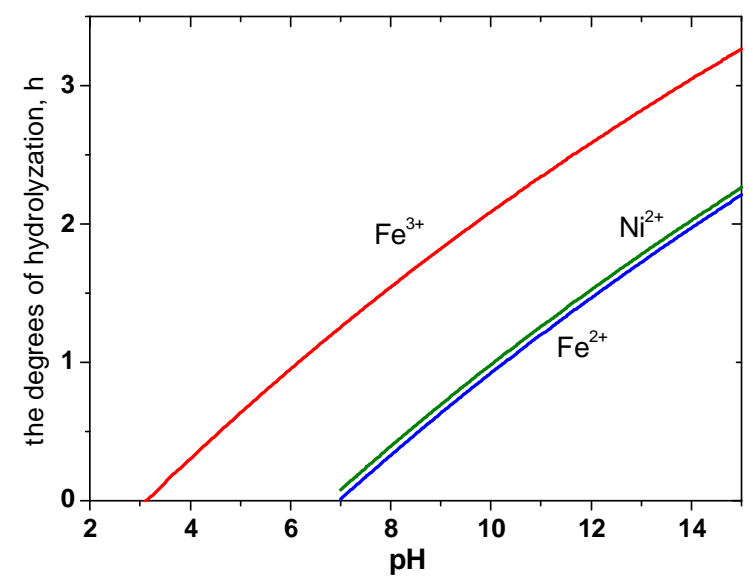

Fig. 1. The protolysis degree of $\left.\mathrm{M}(\mathrm{OH})_{h}\left(\mathrm{OH}_{2}\right)_{6-h}\right]^{(4-h)+}$ $\left(\mathrm{M}=\mathrm{Fe}^{3+}, \mathrm{Fe}^{2+}, \mathrm{Ni}^{2+}\right)$ hydrocompexes vs $\mathrm{pH}$ value of reaction medium.

hydrocomplex is determined by the type of central cation and the hydrolysis degree $(h)$. The theory of partial charge allows calculating the electronegativity of the complex, which allows determining the degree of hydrolysis and defining the most possible nucleation mechanism of the condensed phase [14]. The $\mathrm{pH}$ of the reaction medium is one of the key factors to determine the hydrolysis degree. The electronegativity of water molecules at a $25^{\circ} \mathrm{C}$ is a function of $\mathrm{pH}$ according to the equation: $\chi_{w}=2.732-0.035 \cdot \mathrm{pH}$. The protolysis degree $h$ of $\left[\mathrm{M}\left(\mathrm{OH}_{2}\right)_{N}\right]^{z+}$ species at a certain $\mathrm{pH}$ value can be determined from the condition of equality of the total charge $+(z-h)$ and the sum of charges of all the components of the complex as: $h=\frac{z-n \delta_{O}-2 N \delta_{H}-\delta_{M}}{1-\delta_{H}}$, where $z$ and $n$ are oxidation degrees of the cation and anion, $N$ is a coordination number $(N=6), \delta_{i}=\frac{\left(\chi_{w}-\chi_{i}^{0}\right)}{1.36 \sqrt{\chi_{i}^{0}}}(i=O, H, M)$. The electronegativity values in Allred-Rochow symbols for oxygen, hydrogen, iron and nickel are 3.50, 2.10, 1.72 and 1.80 , respectively [11].

The calculated $\mathrm{h}(\mathrm{pH})$ dependences for the hydrolysis of $\mathrm{Fe}^{3+}, \mathrm{Fe}^{2+}$ and $\mathrm{Ni}^{2+}$ cations under the condition of octahedrally coordinated hydrocomplexes formation (Fig. 1).

The transmission spectra of $0.0001 \mathrm{M}$ iron nitrate aqueous solution were analyzed depending on the $\mathrm{pH}$ value which was determined by ammonia solution adding (Fig. 2, a).

The local decreasing of transmittance was observed at $\mathrm{pH}=6.3$ and $\mathrm{pH}=10.1$ that corresponds to $\left[\mathrm{Fe}(\mathrm{OH})\left(\mathrm{OH}_{2}\right)_{5}\right]^{2+}$ and $\left[\mathrm{Fe}(\mathrm{OH})_{2}\left(\mathrm{OH}_{2}\right)_{4}\right]^{+}-$complexes formation (theoretically predicted values are 6.1 and 9.7, respectively. At the same time the protolysis degree for $\mathrm{Fe}^{2+}$ - and $\mathrm{Ni}^{2+}$ - based hydrocomlexes is about 1 at $\mathrm{pH}=10-11$ and doesn't exseed 2 at $\mathrm{pH}=13-14$. The $\mathrm{pH}$ of the reaction medium at magnetite synthesis was of about $10.5-11.0$ and $\left[\mathrm{Fe}^{(\mathrm{III})}(\mathrm{OH})_{2}\left(\mathrm{OH}_{2}\right)_{4}\right]^{+}$and $\left[\mathrm{Fe}^{(\mathrm{II})}(\mathrm{OH})\left(\mathrm{OH}_{2}\right)_{5}\right]^{+}$are dominated species. In these monorers $\mathrm{OH}$ groups have a thermodynamic preference to basal plane [15].

Three type of olation reactions are possible:

$$
\begin{gathered}
2\left[\mathrm{Fe}^{(\mathrm{III})}(\mathrm{OH})_{2}\left(\mathrm{OH}_{2}\right)_{4}\right]^{+} \rightarrow\left[\mathrm{Fe}^{(\mathrm{III})}{ }_{2}(\mathrm{OH})_{4}\left(\mathrm{OH}_{2}\right)_{6}\right]^{+2}+2 \mathrm{H}_{2} \mathrm{O} \\
\left.\mathrm{Fe}^{(\mathrm{III})}(\mathrm{OH})_{2}\left(\mathrm{OH}_{2}\right)_{4}\right]^{+}+\left[\mathrm{Fe}^{(\mathrm{II})}(\mathrm{OH})\left(\mathrm{OH}_{2}\right)_{5}\right]^{+} \rightarrow\left[\mathrm{Fe}^{(\mathrm{III})} \mathrm{Fe}^{(\mathrm{III})}(\mathrm{OH})_{3}\left(\mathrm{OH}_{2}\right)_{7}\right]^{+2}+2 \mathrm{H}_{2} \mathrm{O} \\
2\left[\mathrm{Fe}^{(\mathrm{II})}(\mathrm{OH})\left(\mathrm{OH}_{2}\right)_{5}\right]^{+} \rightarrow\left[\mathrm{Fe}^{(\mathrm{II})}{ }_{2}(\mathrm{OH})_{2}\left(\mathrm{OH}_{2}\right)_{8}\right]^{+2}+2 \mathrm{H}_{2} \mathrm{O}
\end{gathered}
$$
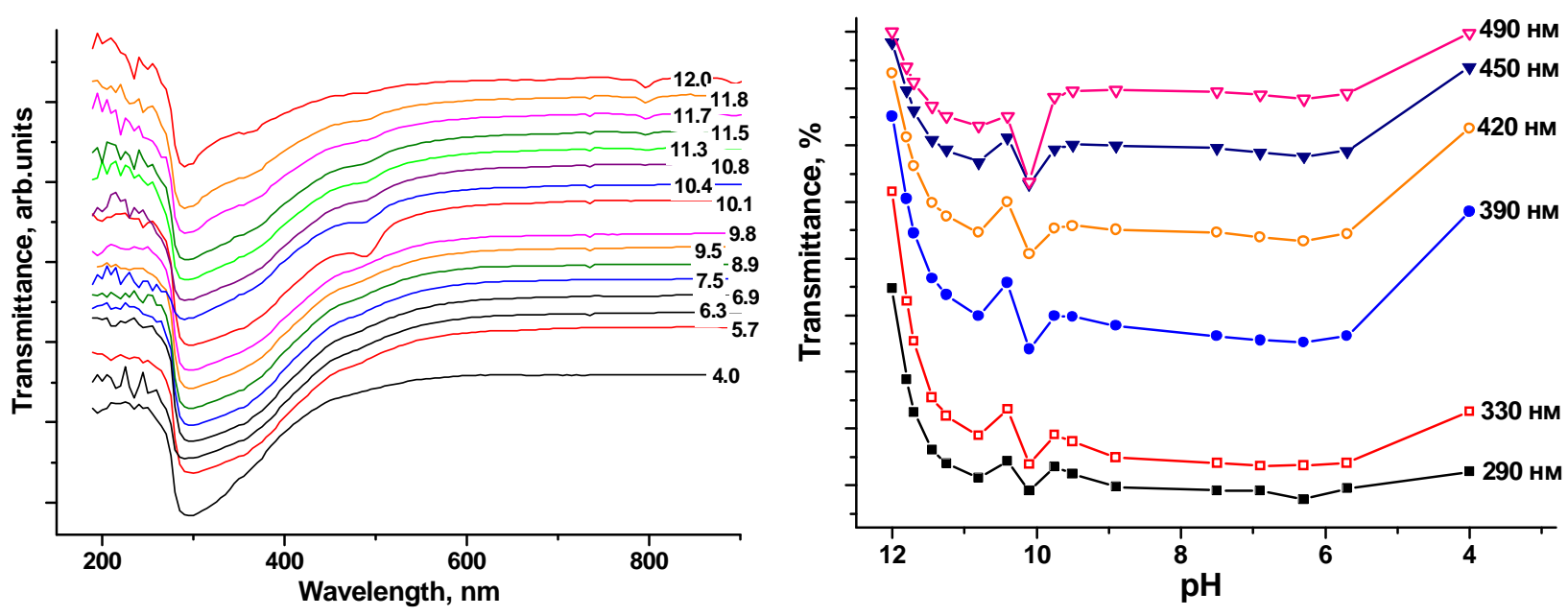

Fig. 2. (a) The transmission spectra of $0.0001 \mathrm{M}$ iron nitrate aqueous solution at different $\mathrm{pH}$ values and (b) transmittance as a function of $\mathrm{pH}$ at different wavelengths. 

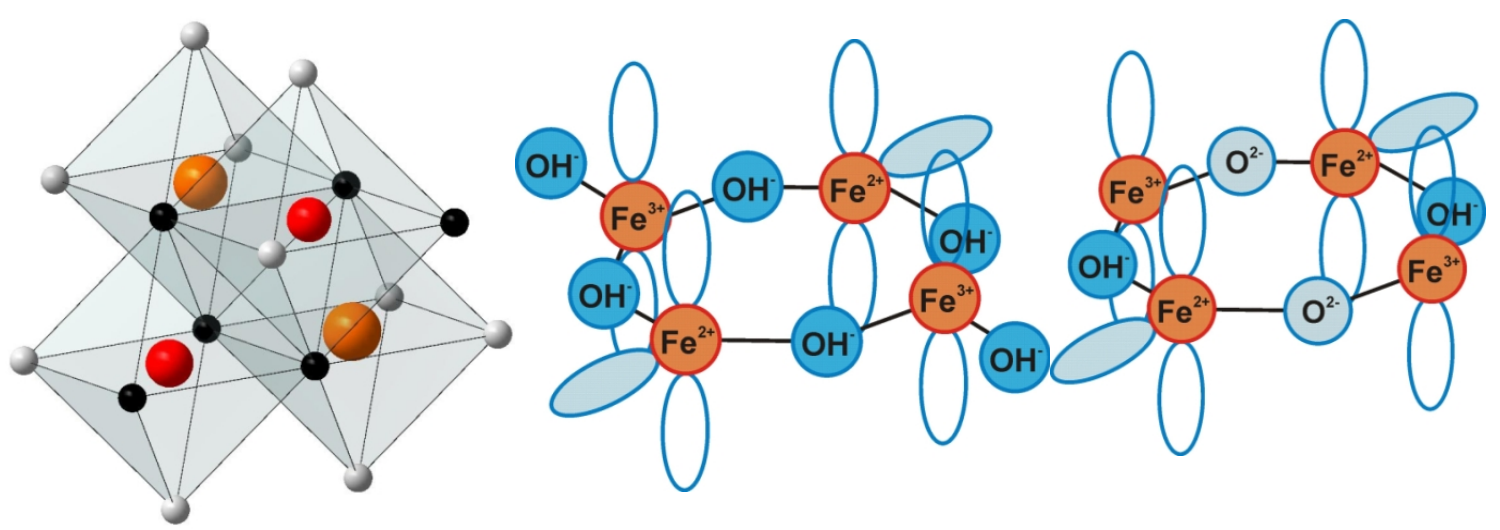

Fig. 3. Models of (a,b) $\left[\mathrm{Fe}^{(I I I)}{ }_{2} \mathrm{Fe}^{(I I)}{ }_{2}(\mathrm{OH})_{6}\left(\mathrm{OH}_{2}\right)_{10}\right]^{+4}$ and (c) $\left[\mathrm{Fe}^{(I I I)}{ }_{2} \mathrm{Fe}^{(I I)}{ }_{2} \mathrm{O}^{2-}(\mathrm{OH})_{2}\left(\mathrm{OH}_{2}\right)_{10}\right]^{+4}$ complexes.

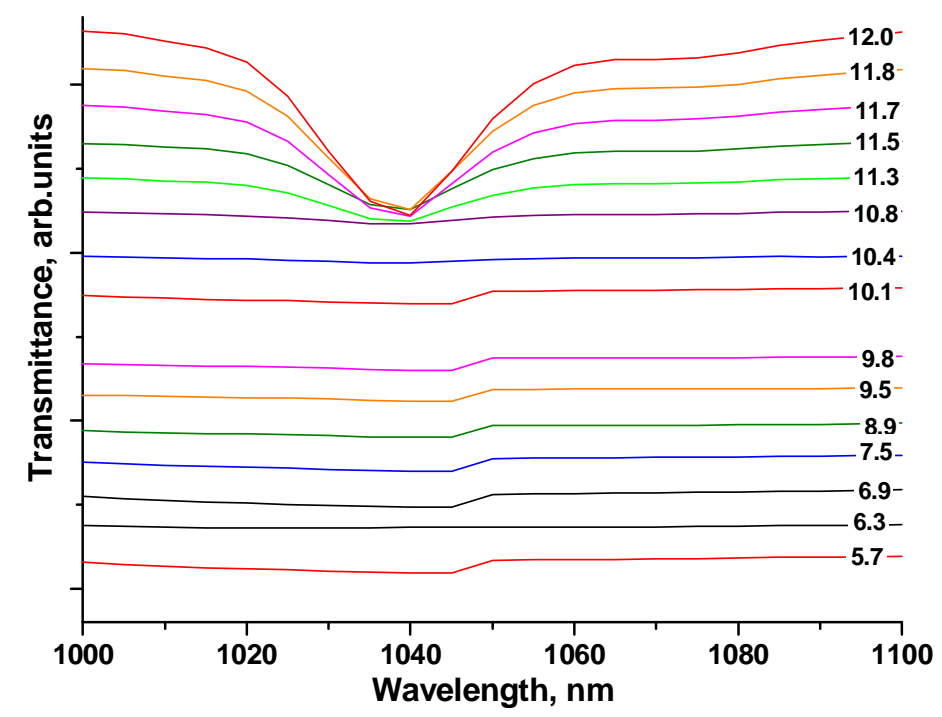

Fig. 4. The transmission spectra of $0.0001 \mathrm{M}$ iron nitrate aqueous solution at different $\mathrm{pH}$ values in a range of 1000-1100 $\mathrm{nm}$.

An additional asymmetry of the tetramer complex formed by both $\mathrm{Fe}^{3+}$ and $\mathrm{Fe}^{2+}$ ions stimulates the olation

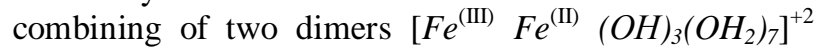
(Fig. 3, a, b) with the possible olation as a next step (Fig. 3, c).

Spectroscopic studies demonstrate changes in the transmittance of the iron nitrate solution at $\mathrm{pH}$ value of about 11.3 that corresponds to the olation-oxolation interactions between $\left[\mathrm{Fe}^{(\mathrm{IIII})}{ }_{2} \mathrm{Fe}^{\text {(II) }}{ }_{2}(\mathrm{OH})_{6}\left(\mathrm{OH}_{2}\right)_{10}\right]^{+4}$ tetramers (Fig. 3) At the next stage the oxolation processes are occured with $\left[\mathrm{Fe}^{\text {(III) }}{ }_{2} \mathrm{Fe}^{\text {(II) }}{ }_{2} \mathrm{O}^{2-}\right.$ $\left.(\mathrm{OH})_{2}\left(\mathrm{OH}_{2}\right)_{10}\right]^{+4}$ complexes formation (Fig. 3,c)

The olation-oxolation reaction and $\left[\mathrm{Fe}^{(\mathrm{III})}{ }_{2} \mathrm{Fe}^{(\mathrm{II})}{ }_{2}(\mathrm{OH})_{6}\left(\mathrm{OH}_{2}\right)_{10}\right]^{4+}$ complexes formation took place with the nucleation of the oxide phase (Fig. 5).

The energy optimization of $\left.\mathrm{Fe}^{(\mathrm{III})}{ }_{2} \mathrm{Fe}^{(\mathrm{II})}{ }_{2}(\mathrm{OH})_{6}\left(\mathrm{OH}_{2}\right)_{10}\right]^{+4}$ complexes can occur accompanied by hydrolysis oxolation transformation of the central zone of the cluster with the formation of $\mathrm{Fe}$ (III) $-\mathrm{O}-\mathrm{Fe}$ (II) bridges:

$$
\begin{aligned}
& {\left[\mathrm{Fe}^{\text {(III) }}{ }_{2} \mathrm{Fe}^{(\mathrm{II})}{ }_{2}(\mathrm{OH})_{6}\left(\mathrm{OH}_{2}\right)_{10}\right]^{+4}+4 \mathrm{H}_{2} \mathrm{O} \rightarrow} \\
& \quad \rightarrow\left[\mathrm{Fe}^{(\mathrm{III})}{ }_{2} \mathrm{Fe}^{(\mathrm{II})}{ }_{2} \mathrm{O}_{4}(\mathrm{OH})_{2}\left(\mathrm{OH}_{2}\right)_{10}\right]^{0} .
\end{aligned}
$$

The formed complexes are electrically neutral that leads to the loss of sol aggregate stability and the starting

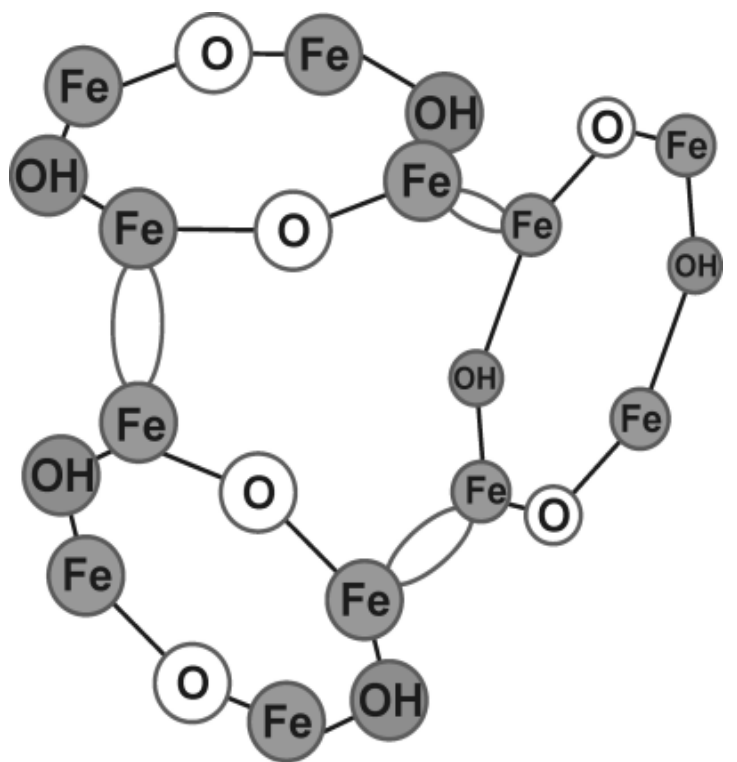

Fig. 5. Probable mechanism of olation-oxolation reactions of iron oxyhydroxide phase nucleation. 

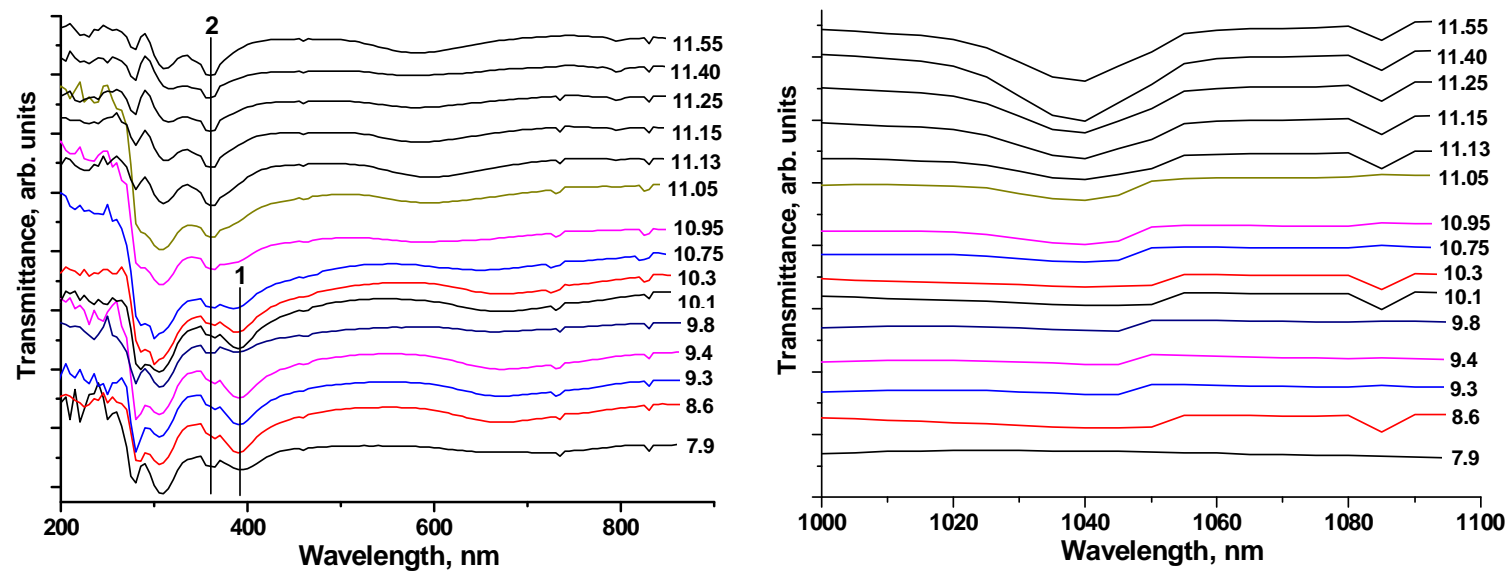

Fig. 6. The transmission spectra of $0.0001 \mathrm{M}$ nickel nitrate aqueous solution at different $\mathrm{pH}$ values.

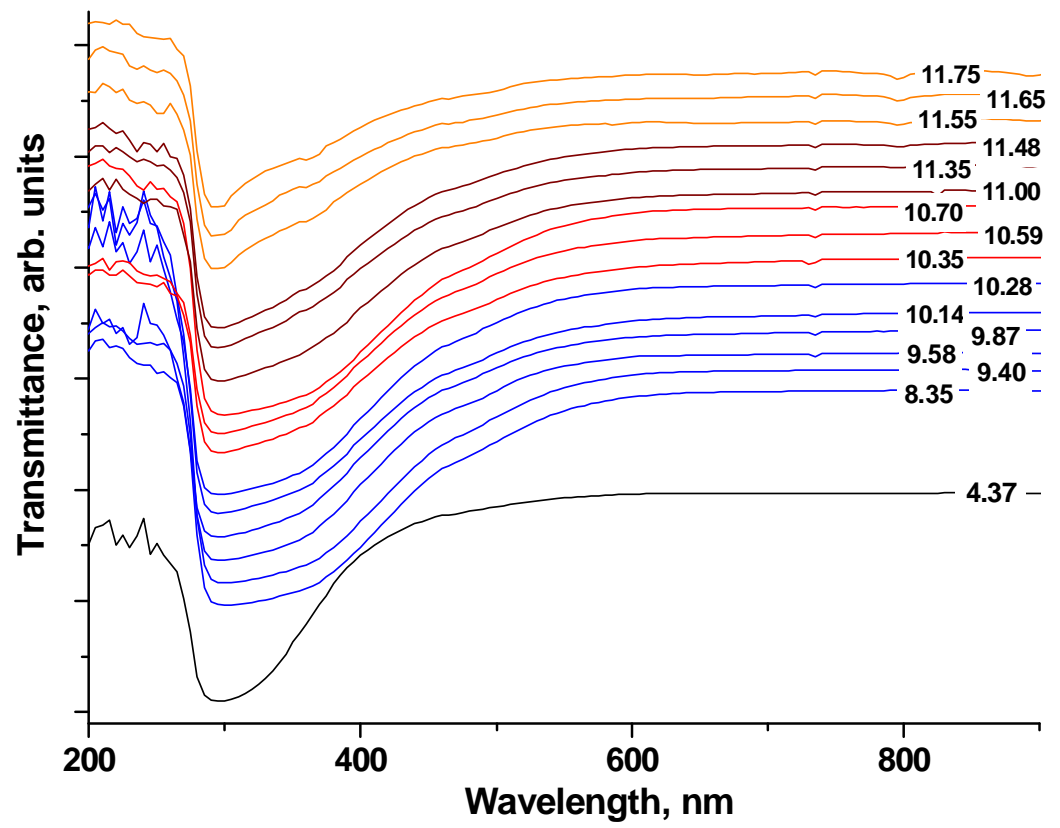

Fig. 7. The transmission spectra of $0.0001 \mathrm{M}$ iron and nickel nitrate aqueous solution (Ni:Fe molar ratio is $1: 2)$ at different $\mathrm{pH}$ values.

of a coagulation. The magnetic ordering has an important role in the processes of clusters organizing at the nucleation stage. Structures of this type were predicted theoretically in [16].

Similar approach was used for the case of the formation and interaction of nickel-based hydrocomplexes. Changes in the transmission spectra of $0.0001 \mathrm{M}$ nickel nitrate aqueous solution at increasing of $\mathrm{pH}$ were analyzed (Fig. 6). A redistribution of a transmittance between the spectral regions in the vicinity of $390 \mathrm{~nm}$ and $360 \mathrm{~nm}$ was found at $\mathrm{pH}$ value in a range of 10.75-10.95 (Fig. 6, a). According to PCM the formation of $\left[\mathrm{Ni}^{\text {(II) }}(\mathrm{OH})\left(\mathrm{OH}_{2}\right)_{5}\right]^{+}$hydrocomplexes occurs at $\mathrm{pH}$ values of about $10.0-10.5$ (Fig. 1) At the same time, an increase in the absorption coefficient in the vicinity of $1040 \mathrm{~nm}$ was observed, that may be the evidence of the possible formation of low-dimensional polymeric complexes like $\left[\mathrm{Ni}_{2}(\mathrm{OH})_{2}\left(\mathrm{OH}_{2}\right)_{8}\right]^{0}$ (Fig. 6, b).
Nickel ferrite nucleation takes place according to a scheme similar to the formation of magnetite with the $\mathrm{Ni}^{2+}$-based hydrocomplexes instead $\mathrm{Fe}^{2+}$. Spectrophotometric studies of the mixture of $0.0001 \mathrm{M}$ iron and nickel nitrate aqueous solutions ( $\mathrm{Fe}: \mathrm{Ni}$ molar ratio is 2:1) were carried out at different $\mathrm{pH}$ values. The transmission spectra at $\mathrm{pH}>10.28$ were observed (Fig. 7).

The formation of $\left[\mathrm{Fe}^{(\mathrm{III})}{ }_{2}(\mathrm{OH})_{4}\left(\mathrm{OH}_{2}\right)_{6}\right]^{+2}$, $\left[\mathrm{Fe}^{(\mathrm{III})} \mathrm{Fe}^{(\mathrm{III})}(\mathrm{OH})_{3}\left(\mathrm{OH}_{2}\right)_{7}\right]^{+2}, \quad\left[\mathrm{Fe}^{(\mathrm{II})}{ }_{2}(\mathrm{OH})_{2}\left(\mathrm{OH}_{2}\right)_{8}\right]^{+2}$, and also $\left[\mathrm{Fe}^{\text {(III) }} \mathrm{Ni}^{\text {(II) }}(\mathrm{OH})_{3}\left(\mathrm{OH}_{2}\right)_{7}\right]^{+2}$ and $\left[\mathrm{Ni}^{\text {(II) }}{ }_{2}(\mathrm{OH})_{2}\left(\mathrm{OH}_{2}\right)_{8}\right]^{+2}$ complexes is probable. At $\mathrm{pH}$ values of about 11.0 the formation of $\left[\mathrm{Fe}^{(\mathrm{III})}{ }_{2} \mathrm{Fe}^{(\mathrm{III})} \mathrm{Ni}^{\text {(II) }} \mathrm{O}^{2-}(\mathrm{OH})_{2}\left(\mathrm{OH}_{2}\right)_{10}\right]^{+4}$ complexes begins with the next olation and oxolation (Fig. 5). These processes leads to complex oxyhydroxydes spieces formation which are the centers of spinel phase nucleation. 

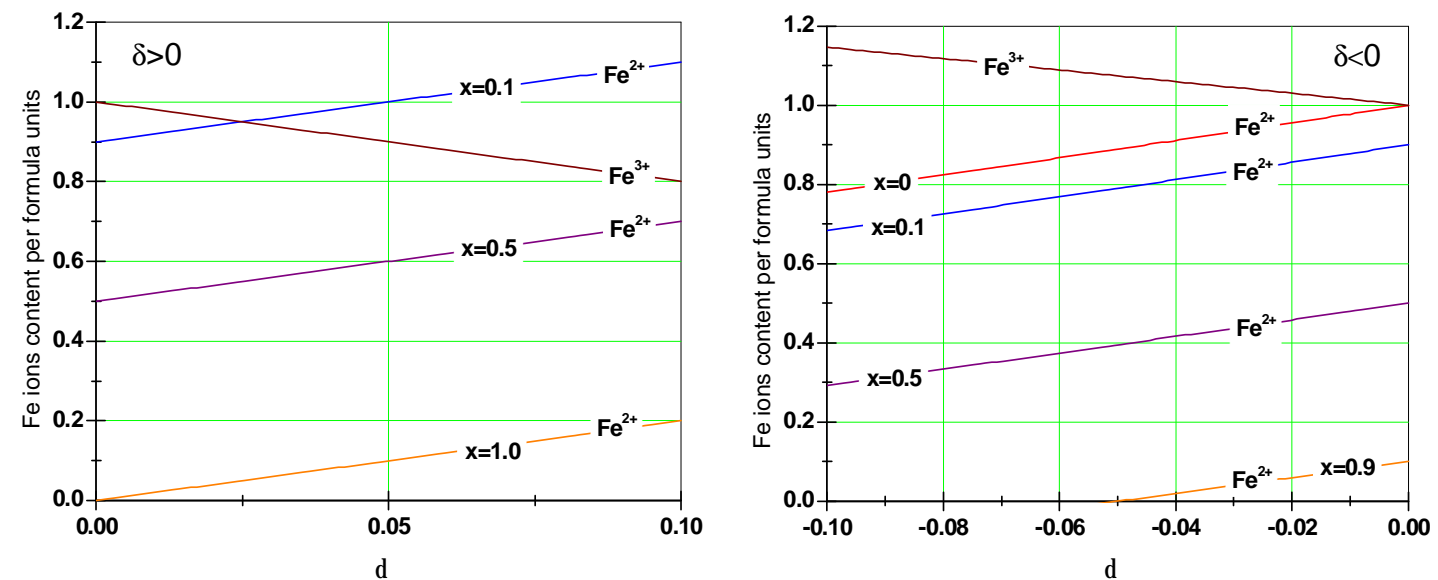

Fig. 8. The dependencies of octahedrally coordinated $\mathrm{Fe}$ ions content in $\mathrm{Ni}_{x} \mathrm{Fe}_{3-x} \mathrm{O}_{4-\delta}$ spinel lattice as a function of oxygen non-stoichiometry: (a) $\delta>0$ and (b) $\delta<0$.

\section{Crystal-quasichemical analysis of nikel iron spinel nucleation and properties}

The precipitation synthesis from mixture of nickel and both (II) and (III) iron aqueous solutions was performed. Ammonium hydroxide solution was used for increasing of $\mathrm{pH}$ value of reacton medium up to 11-12. The next equation describes the starting stage of synthesis: $\mathrm{FeCl}_{2}+2 \mathrm{NH}_{4} \mathrm{OH} \rightarrow \mathrm{Fe}(\mathrm{OH})_{2}+2 \mathrm{NH}_{4} \mathrm{Cl}$ and $\mathrm{NiCl}_{2}+2 \mathrm{NH}_{4} \mathrm{OH} \rightarrow \mathrm{Ni}(\mathrm{OH})_{2}+2 \mathrm{NH}_{4} \mathrm{Cl}$. The $\mathrm{Fe}(\mathrm{III})$ hydroxyde is unstable [17] and decomposes to $\mathrm{FeO}(\mathrm{OH})$ oxyhydroxide as follows:

$$
2 \mathrm{FeCl}_{3}+6 \mathrm{NH}_{4} \mathrm{OH}+(n-3) \mathrm{H}_{2} \mathrm{O} \rightarrow \mathrm{FeO}_{3} \mathrm{nH}_{2} \mathrm{O}+6 \mathrm{NH}_{4} \mathrm{Cl} \rightarrow \mathrm{FeO}(\mathrm{OH}) n \mathrm{H}_{2} \mathrm{O}+6 \mathrm{NH}_{4} \mathrm{Cl}
$$

. The spinel structure formation can be formally represented as a result of interaction of $\mathrm{FeOOH}, \mathrm{Fe}(\mathrm{OH})_{2}$ and $\mathrm{Ni}(\mathrm{OH})_{2}$ precursors as:

$$
\beta-\mathrm{FeOOH}+x \mathrm{Ni}(\mathrm{OH})_{2}+(x-1) \mathrm{Fe}(\mathrm{OH})_{2} \rightarrow \mathrm{Ni}_{x} \mathrm{Fe}_{1-x} \mathrm{Fe}_{2} \mathrm{O}_{4}+\mathrm{H}_{2} \mathrm{O}
$$

Crystalline structure of ferric spinel (space group $\mathrm{Fd} 3 \mathrm{~m}$ ) is based on a cubic lattice of the oxygen ions and consists of $32 \mathrm{O}^{2-}$ anions, $16 \mathrm{Fe}^{3+}$ cations and also $8 \mathrm{Me}^{2+}$ cations in each unit cell ( $\mathrm{Me}=\mathrm{Ni}, \mathrm{Ci}, \mathrm{Zn}$, etc). There are 64 tetrahedral (A) sites and 32 octahedral (B) ones per unit cell. The cation distribution is described as $(\mathrm{Me})_{\mathrm{A}}\left[\mathrm{Fe}_{2}\right]_{B} \mathrm{O}_{4}$ where the semicircle and square brackets indicate the tetrhedral and octahedral sites, respectively. There are two limit type of cation distribution e. g. normal and inverse spinel. In normal spinel the divalent ions are located in tetrahedral B-sites when trivalent cations are in B-sites only. Nickel ferrite $\mathrm{Ni}_{x} \mathrm{Fe}_{3-x} \mathrm{O}_{4}$ is an inverse spinel where $\mathrm{Ni}^{2+}$ ions occupy B-sites only and the $\mathrm{Fe}^{3+}$ ions are distributed in $\mathrm{A}-$ and $\mathrm{B}$-sites. The presence of octahedrally coordinated $\mathrm{Fe}^{2+}$ is required condition for electrical neutrality of a lattice at $0<x<1$.

Crystal-quasichemical approach is based on the analysis of superposition result of basic matrix antistructure and the crystallochemical formula of the

\section{compound} $\left(V_{F e}^{\prime \prime \prime}\right)\left[\left\langle V_{N i}^{\prime \prime}\right\rangle_{x}\left\langle V_{F e}^{\prime \prime}\right\rangle_{1-x} V_{F e}^{\prime \prime \prime}\right]_{B}\left\{V_{4}^{\bullet \bullet}\right\}_{O}$ cluster is a result of sequential "removal" of ions from cationic and anionic sublattice of $\left(\mathrm{Fe}^{3+}\right)_{A}\left[\mathrm{Ni}_{x}^{2+} \mathrm{Fe}_{2-x}^{3+}\right]_{B}\left\{\mathrm{O}_{4}^{2-}\right\}_{O}$ as a basic structure. The Kröger's formalism was used where $V_{A}^{\prime \prime}$ and $\mathrm{V}_{\mathrm{B}}^{\prime \prime \prime}$ are double- and triple- charged vacancies, respectively and "/", "•" and "x" symbols denote negative, positive and neutral charges, respectively. According to PCM theory the olation-oxolation processes with participation of $\mathrm{Fe}^{3+}$-based hydrocomplexes occur at relatively low $\mathrm{pH}$ value of reaction medium. The increasing of $\mathrm{pH}$ value leads to $\mathrm{Fe}^{2+}$ - and $\mathrm{Ni}^{2+}$-based complexes formation and the nucleation of nickel-ion spinel. Stoichiometric spinel structure is a result of superposition of these clusters:

$$
\begin{aligned}
& x\left(F e^{\bullet}\right)_{A}\left[F e^{\times} N i^{\prime}\right]_{B}\left(O_{4}^{\times}\right)_{O}+(1-x)\left(F e^{\bullet}\right)_{A}\left[F e^{\times} F e^{\prime}\right]_{B}\left(O_{4}^{\times}\right)_{O} \rightarrow \\
& \rightarrow\left(F e_{x}^{\bullet} F e_{1-x}^{\bullet}\right)_{A}\left[F e_{x}^{\times} F e_{1-x}^{\times} N i_{x}^{\prime} F e_{1-x}^{\prime}\right]_{B}\left(O_{4 x}^{\times}\right)_{O}\left(O_{4(1-x)}^{\times}\right)_{O} \rightarrow \\
& \rightarrow\left(F e^{\bullet}\right)_{A}\left[F e^{\times} N i_{x}^{\prime} F e_{1-x}^{\prime}\right]_{B}\left(O_{4}^{\times}\right)_{O} \rightarrow\left(F e^{\times}\right)_{A}\left[F e^{\times} N i_{x}^{\times} F e_{1-x}^{\times}\right]_{B}\left(O_{4}^{\times}\right)_{O}
\end{aligned}
$$

The deviation of $\mathrm{Ni}_{x} \mathrm{Fe}_{3-x} \mathrm{O}_{4-\delta}$ spinel from stoichiometric one can be defined using $\delta$ parameter. The vacancies in the 
oxygen sublattice correspond to positive $\delta$ when vacancies in the cationic one correspond to negative $\delta$ values [20]:

$$
\begin{gathered}
\delta>0 \Rightarrow N i_{x} F e_{3-x} O_{4-\delta}=\left(F e^{3+}\right)\left[N i_{x}^{2+} F e_{1-x+2 \delta}^{2+} F e_{1-2 \delta}^{3+}\right]\left\{O_{4-\delta}\right\} \\
\delta<0 \Rightarrow N i_{x} F e_{3-x} O_{4-\delta}=N i_{\frac{4 x}{4-\delta}} \frac{-3 \delta}{4-\delta} F e_{\frac{3-x}{4-\delta}} O_{4}=(F e)\left[N i_{\frac{4 x}{4-\delta}}^{2+} F e_{\frac{4(1-x+2 \delta)}{4-\delta}}^{2+} F e_{\frac{(4-7 \delta)}{4-\delta}}^{3+} \frac{0}{4-\delta}\right]\left\{O_{4}\right\} .
\end{gathered}
$$

The concentration of oxygen vacancies for $\mathrm{NiFe}_{2} \mathrm{O}_{4}$ nanoparticles obtained in aqueous medium is up to about 0.10 per formula unit [21]. The $\mathrm{Fe}^{2+}$ content decreases drastically with the increasing of $\mathrm{Ni}^{2+}$ concentration and at different values of oxygen non-stoichiometry when $\mathrm{Fe}^{3+}$ content doesn't depend on the presence of $\mathrm{Ni}^{2+}$ ions (Fig. 8, a,b). At the same time the presence of the oxygen excess leads to non-linear growth of cation vacancies concentration located in octahedral site. The next analysis can be done applying basic crystal quasichemistry approaches at $\delta>0$ and $\delta<0$ :

$$
\begin{aligned}
& \delta \geq 0 \Rightarrow\left(V_{F e}^{\prime \prime \prime}\right)_{A}\left[\left\langle V_{N i}^{\prime \prime}\right\rangle_{x}\left\langle V_{F e}^{\prime \prime}\right\rangle_{1-x} V_{F e}^{\prime \prime \prime}\right]_{B}\left\{V_{4}^{\bullet \bullet}\right\}_{O}+\left(F e^{3+}\right)_{A}\left[N i_{x}^{2+} F e_{1-x+2 \delta}^{2+} F e_{1-2 \delta}^{3+}\right]_{B}\left\{O_{4-\delta}^{2-}\right\}_{O} \rightarrow \\
& \rightarrow\left(F e^{\times}\right)_{A}\left[N i_{x}^{\times} F e_{1-x}^{\times} F e_{2 \delta}^{\prime} F e_{1-2 \delta}^{\times}\right]_{B}\left\{O_{4-\delta}^{\times} V_{\delta}^{\bullet \bullet}\right\}_{O} \\
& \delta<0 \Rightarrow\left(V_{F e}^{\prime \prime \prime}\right)_{A}\left[\left\langle V_{N i}^{\prime \prime}\right\rangle_{x}\left\langle V_{F e}^{\prime \prime}\right\rangle_{1-x} V_{F e}^{\prime \prime \prime}\right]_{B}\left\{V_{4}^{\bullet \bullet}\right\}_{O}+(F e)_{A}\left[\begin{array}{cc}
N i_{\frac{4 x}{4-\delta}}^{2+} F e_{\frac{4(1-x+2 \delta)}{4-\delta}}^{2+} F e_{\frac{4-7 \delta}{4-\delta}}^{3+} & 0 \\
\frac{-3 \delta}{4-\delta}
\end{array}\right]_{B}\left\{O_{4}^{2-}\right\}_{O} \rightarrow
\end{aligned}
$$

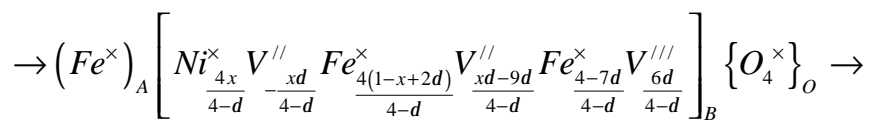

$$
\begin{aligned}
& \rightarrow\left(F e^{\times}\right)_{A}\left[N i_{\frac{4 x}{4-\delta}}^{\times} F e_{\frac{4(1-x+2 \delta)}{4-\delta}}^{\times} F e_{\frac{4-7 \delta}{4-\delta}}^{\times} V_{\frac{-9 \delta}{4-\delta}}^{\prime \prime} V_{\frac{6 \delta}{4-\delta}}^{\prime \prime \prime}\right]_{B}\left\{O_{4}^{\times}\right\}_{O}
\end{aligned}
$$

The crystalquasichemical formulas obtained at $\delta>0$ demonstrates the presence of non-compensated negative charge per formula unit in B-sublattice of $\mathrm{Ni}_{x} \mathrm{Fe}_{3-x} \mathrm{O}_{4-\delta}$ spinel. The electrical neutrality of whole lattice is provided by the presence of anionic vacancies. The neutrality of crystal lattice at $\delta<0$ is a result of mutual charge compensation in the octahedral sublattice. These conclusions are important for the prediction of chemical activity and adsorbtion mechanisms on surfaces of defect crystals [22]. Another important characteristic that depends on the stoichiometry and cation distribution is an electical conductivity of the material. It is known that the electron hopping between octahedrally coordinated $\mathrm{Fe}^{2+}$ and $\mathrm{Fe}^{3+}$ ions (activation energy about $0.45 \mathrm{eV}$ ) is

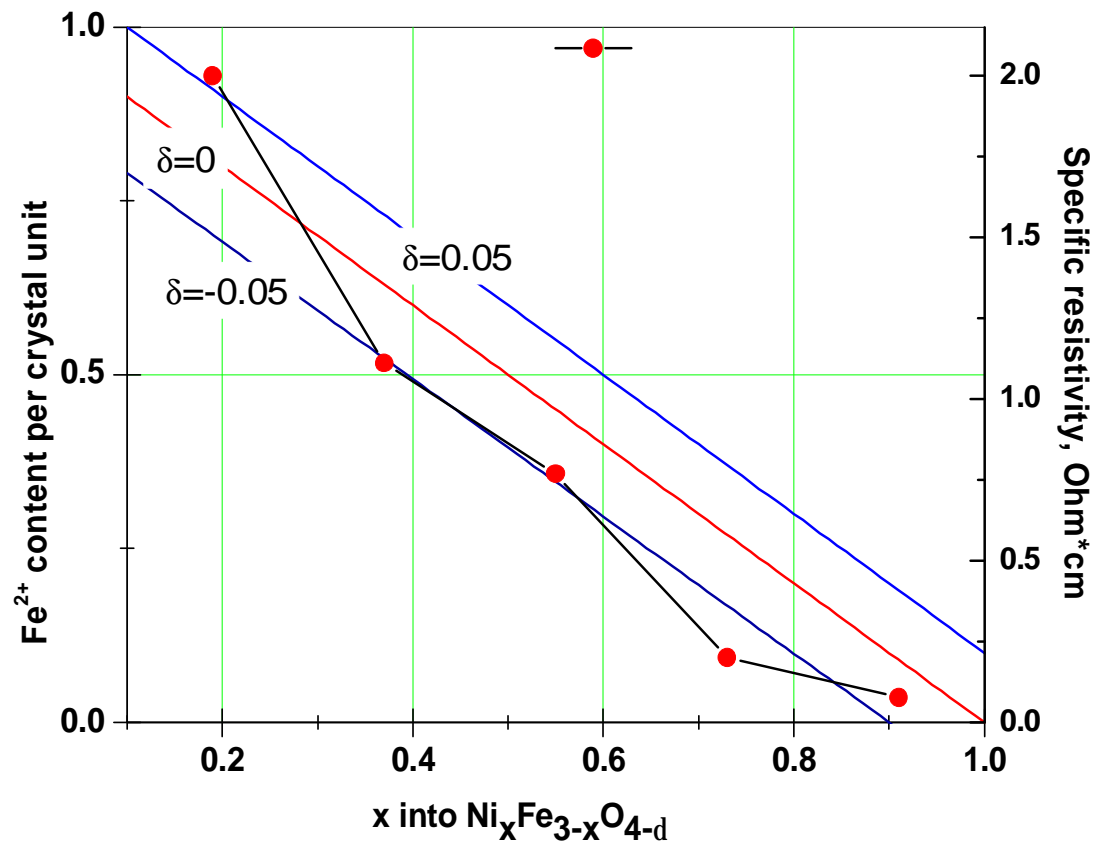

Fig. 9. The dendencies of (a) $\mathrm{Fe}^{2+}$ ions content in B-sites and (b) specific electrical conductivity of $\mathrm{Ni}_{x} \mathrm{Fe}_{3-x} \mathrm{O}_{4-\delta}$ spinel as a function of $\mathrm{Ni}^{2+}$ atoms concentration. 
the dominant mechanism of electrical conductivity of bulk $\mathrm{NiFe}_{2} \mathrm{O}_{4}$ [23]. The increasing of the specific electrical conductivity of $\mathrm{Ni}_{x} \mathrm{Fe}_{3-x} \mathrm{O}_{4}$ spinel at the increase in $\mathrm{Ni}^{2+}$ ions content was observed experimentally in [24].

The changes in $\mathrm{Fe}^{2+}$ ions content in B-sites of $\mathrm{Ni}_{x} \mathrm{Fe}_{3-x} \mathrm{O}_{4-\delta}$ spinel at increasing of $\mathrm{Ni}^{2+}$ concetration corelate with specific electrical conductivity dependency (Fig. 9), but the oxygen non-stoichiometry can cause the additional influence on the electrical characteristics of the material. The analysis of an electron percolation was done in the crystal-quasichemical terms:

$$
\begin{aligned}
& \delta \geq 0 \Rightarrow\left(F e^{\times}\right)_{A}\left[N i_{x}^{\times}\left\langle F e_{1-x}^{\times}\right\rangle\left\langle F e_{2 \delta}^{\prime}\right\rangle\left\langle F e_{1-2 \delta}^{\times}\right\rangle\right]_{B}\left\{O_{4-\delta}^{\times} V_{\delta}^{\bullet \bullet}\right\}_{O} \rightarrow\left(F e^{2+} \Leftrightarrow F e^{3+}\right) \rightarrow \\
& \rightarrow\left(F e^{\times}\right)_{A}\left[N i_{x}^{\times}\left\langle F e_{2-2 x}^{\times}\right\rangle F e_{x-2 \delta}^{\times} F e_{2 \delta}^{\prime}\right]_{B}\left\{O_{4-\delta}^{\times} V_{\delta}^{\bullet \bullet}\right\}_{O} \\
& \delta<0 \Rightarrow\left(F e^{\times}\right)_{A}\left[N \frac{i_{\frac{4 x}{4}}^{\times}}{4-\delta} e_{\frac{4(1-x+2 \delta)}{4-\delta}}^{\times} F e_{\frac{4-7 \delta}{4-\delta}}^{\times} V_{\frac{-9 \delta}{4-\delta}}^{\prime \prime} V_{\frac{6 \delta}{4-\delta}}^{\prime \prime \prime}\right]_{B}\left\{O_{4}^{\times}\right\}_{O} \rightarrow\left(F e^{2+} \Leftrightarrow F e^{3+}\right) \rightarrow \\
& \rightarrow\left(F e^{\times}\right)_{A}\left[N i_{\frac{4 x}{4-\delta}}^{\dot{x}^{\prime}}\left\langle F e_{\frac{4 x-15 \delta}{4-\delta}}^{\times}\right\rangle F e_{\frac{8-8 x+16 \delta}{4-\delta}}^{\times} \frac{V_{-9 \delta}^{\prime \prime}}{4-\delta} \frac{V_{6 \delta}^{\prime \prime \prime}}{4-\delta}\right]_{B}\left\{O_{4}^{\times}\right\}_{O}
\end{aligned}
$$

As follows under $\delta>0$ condition the concentration of exchange pairs linearly decreases with $\mathrm{Ni}^{2+}$ content increasing regardless of oxygen non-stoichiometry. The presence of cation vacancies in B-sites $(\delta<0)$ causes more complex behaviour that corresponds to increase in exchange pairs $\mathrm{Fe}^{2+} \leftrightarrow \mathrm{Fe}^{3+}$ concentration with the increasing of $\delta$.

The crystallochemical approach allows us to establish the relationship between the cations distribution and the geometry of crystal lattice. The semiempirical correlations between the parameters of the nickel ferrite lattice and the crystallographic parameters (the ratio of nickel cations to iron cations, the availability of vacancies in cationic and anionic sublattices, and deviation from oxygen stoichiometry) can be calculated.

Each anion in the crystal spinel lattice is surrounded by one tetrahedrically coordinated and three octahedronically coordinated cations. The displacement of one of the anions determines the change in the coordinates of the other atoms. The change in bondlengths causes the interlattice stresses. The mimimization of a resulting energy of an elastic deformation determines the equilibrium value of the lattice parameter. The correlation between ion radii of the lattice component and interatomic distances is caused by close-packing character of a spinel structure. There is a number of semiempirical models that calculate the lattice parameter as a function of distances between anion and cation, type, coordination number and ions oxidation degree [25]. The development of [26] approach was implemented in our case which is based on using the configuration matrix $\left(\begin{array}{lll}S_{11} & S_{12} & S_{13} \\ S_{21} & S_{22} & S_{23}\end{array}\right)$, where $\mathrm{S}_{11}, \mathrm{~S}_{12}$ and $\mathrm{S}_{13}$ matrix elements are concentrations of $\mathrm{Ni}^{2+}, \mathrm{Fe}^{2+}$ and $\mathrm{Fe}^{3+}$ in tetrahedral lattice positions and $\mathrm{S}_{21}, \mathrm{~S}_{22}$ and $\mathrm{S}_{23}$ are concentrations of these ions in octahedral sites. This matrix for a case of $\delta>0$ and $\left(F e^{3+}\right)_{A}\left[N i_{x}^{2+} F e_{1-x+2 \delta}^{2+} F e_{1-2 \delta}^{3+}\right]_{B}\left\{O_{4-\delta}^{2-}\right\}_{O}$ can be written as

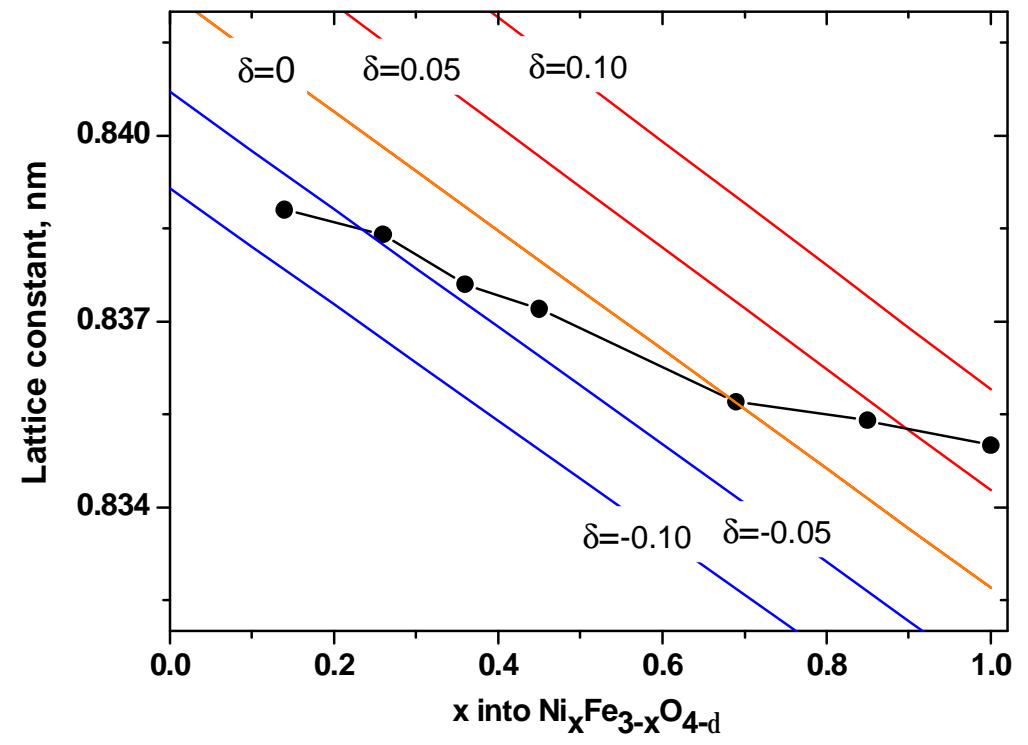

Fig. 10. The theoretical dependencies of lattice constant of $\mathrm{Ni}_{x} \mathrm{Fe}_{3-x} \mathrm{O}_{4-\delta}$ spinel on $\mathrm{Ni}^{2+}$ concetration at differeent values of oxygen non-stoichiometry $\delta$. 


$$
\begin{aligned}
& \left(\begin{array}{ccc}
0 & 0 & 1 \\
x & 1-x+2 \delta & 1-2 \delta
\end{array}\right) \text {. The case of } \delta>0 \text { and } \\
& (\mathrm{Fe})_{A}\left[N i_{\frac{4 x}{4-\delta}}^{2+} F e_{\frac{4(1-x+2 \delta)}{4-\delta}}^{2+} F e_{\frac{4-7 \delta}{4-\delta}}^{3+} \frac{0}{4-\delta}\right]_{B}\left\{\mathrm{O}_{4}^{2-}\right\}_{O} \text { is described as }
\end{aligned}
$$$$
\left(\begin{array}{ccc}
0 & 0 & 1 \\
\frac{4 x}{4-\delta} & \frac{4(1-x+2 \delta)}{4-\delta} & \frac{4-7 \delta}{4-\delta}
\end{array}\right) \text {. The lattice parameter }
$$$$
\text { equation can be represented as: }
$$

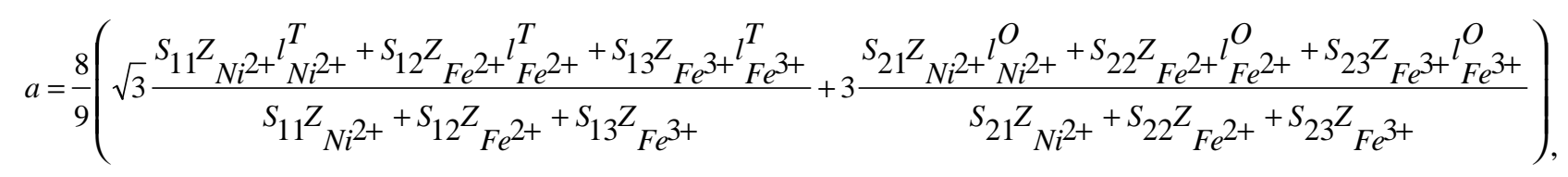

where $l_{M e}^{T, O}$ are corresponding unstrained metal-anion distances in tetrahedral and octahedral coordinations [25], $Z_{M e}$ are ion charges. The lattice parameter dependencies as functions of $\mathrm{Ni}^{2+}$ ion concentration were compared to experimental data from [27] (Fig. 10)

It can be assumed that the case of negative values of oxygen non-stoichiometry $\delta$ with the formation of cation vacancies in the B-sites are the most probable at relatively low (0.0-0.4 at per formula unit) concentration of $\mathrm{Ni}^{2+}$ ions for $\mathrm{Ni}_{x} \mathrm{Fe}_{3-x} \mathrm{O}_{4-\delta}$ spinel structure. For the same case the increasing of substitution degree leads to changes in the predominant defect type wtih the anionic non-stoichiometry predomination.

\section{Conclusions}

The hydrolysis of iron and nickel salts was analysed from the point of view of partial charge theory. A relationship between the $\mathrm{pH}$ and the hydrolysis degree (h) was defined. It is assumed that nucleation of specific polymorph is caused by spatial arrangement of the primary monomers $\left.\mathrm{M}(\mathrm{OH})_{h}\left(\mathrm{OH}_{2}\right)_{6-h}\right]^{(4-h)+} \quad\left(\mathrm{M}=\mathrm{Fe}^{3+}\right.$, $\left.\mathrm{Fe}^{2+}, \mathrm{Ni}^{2+}\right)$ during the polycondensation. UV-vis spectroscopy allowed to observe the changes of optical transmission of iron nitrate and nickel nitrate aqueous solution at predicted $\mathrm{pH}$ values which correspond to formation of different types of hydrocomplexes. In particular, at $\mathrm{pH}$ values of about 11.0 the formation of $\left[\mathrm{Fe}^{(\mathrm{III})}{ }_{2} \mathrm{Fe}^{(\mathrm{III})} \mathrm{Ni}^{(\mathrm{II})} \mathrm{O}^{2-}(\mathrm{OH})_{2}\left(\mathrm{OH}_{2}\right)_{10}\right]^{+4}$ complexes begins with the next olation and oxolation and this leads to nucleation of oxyhydroxydes as centers of spinel phase formation. The crystal-quasichemical analysis revealed the precence of non-compensated negative charge in $\mathrm{B}$ sublattice of $\mathrm{Ni}_{x} \mathrm{Fe}_{3-x} \mathrm{O}_{4-\delta}$ spinel at $\delta>0$ values when electrical neutrality of crystall lattice at $\delta<0$ is a result of mutual charge compensation in the octahedral sublattice. Under $\delta>0$ condition the concentration of $\mathrm{Fe}^{2+} \leftrightarrow \mathrm{Fe}^{3+}$ pairs, that are responsible to percolation-type elelctrical conductivity, linearly decreases with increasing of $\mathrm{Ni}^{2+}$ regardless to anionic non-stoichiometry. Under the condition of $\delta<0$ the formation of cation vacancies in octahedral sublattice is probable at $\mathrm{Ni}^{2+}$ ions concentration $<0.4$ per formula unit when the anionic non-stoichiometry is predominant at relatively higher values of $\mathrm{Ni}^{2+}$ ions concentration.

Boychuk V. - PhD (chemical sciences), associate professor of the department of theoretical and experimental physics, associate professor of the department of physics and teaching methods;

Kotsyubynsky $\boldsymbol{V}$. - PHD (physics and mathematics sciences), professor of the department of materials science and new technologies;

Bandura K. - assistant professor of department of medical informatics, medical and biological physics;

Hodlevska M. - postgraduate of the department of materials science and new technologies;

Dzundza B. - PhD (physics and mathematics sciences), associate professor of the department of safety of life;

Khatsevych $\boldsymbol{O}$. - PhD (technical sciences), associate professor of the department of chemistry..

[1] M.A. Li, L. Zhang, X. B. Li, Z. Y. Li, K. C. Zhou, Trans. Nonferrous Met. Soc. China 25(1), 146 (2015).

[2] S. Zhang, J. Shan, L. Nie, L. Nguyen, Z. Wu, F.F. Tao, Surf. Sci. 648, 156 (2016).

[3] Y. Liu, Y. Song, Y. You, X. Fu, J. Wen, X. Zheng, J. Saudi Chem. Soc. 22(4), 439 (2018).

[4] V. Nagarajan, R. Chandiramouli, arXiv preprint arXiv 1706, 10148 (2017).

[5] V. Manikandan, X. Li, R. S. Mane, J. Chandrasekaran, J. Electron. Mater. 47, 3403 (2018).

[6] J. Kudr, Y. Haddad, L. Richtera, Z. Heger, M. Cernak, V. Adam, O. Zitka, Nanomater. 7(9), 243 (2017).

[7] C. Sun, J.S. Lee, M. Zhang, Adv. Drug Delivery Rev. 60(11), 1252 (2008).

[8] L. Chauhan, A. K. Shukla, K. Sreenivas, Ceram. Int. 42(10), 12136 (2016).

[9] J. Tan, W. Zhang, A.L. Xia, Mater. Res. 16(1), 237 (2013).

[10] Z.K. Karakaş, R. Boncukçuoğlu, İ.H. Karakaş, J. Phys.: Conf. Ser. 707, 012046 (2016).

[11] M. Henry, J.P. Jolivet, J. Livage, Struct. Bonding 77, 153 (1992).

[12] W. Schneider, Comments Inorg. Chem. 3(4), 205 (1984). 
[13] T.K. Sham, J.B. Hastings, M.L. Perlman, J. Am. Chem. Soc. 102(18), 5904 (1980).

[14] V.O. Kotsyubynsky, I.F. Myronyuk, L.I. Myronyuk, V.L. Chelyadyn, M.H. Mizilevska, A.B. Hrubiak, F.M. Nizamutdinov, Materialwiss. Werkstofftech. 47(2-3), 288 (2016).

[15] R.L. Martin, P.J. Hay, L.R. Pratt, J. Phys. Chem. A 102(20), 3565 (1998).

[16] C.F. Baes Jr, R.E. Mesmer The hydrolysis of cations (John Wiley and Sons: Hoboken: 1976).

[17] Li Hua, Wu Hua-zhong, Xiao Guo-xian, 198, 157 (2010).

[18] С.С. Лисняк, Неорганические материалы 28(9), 1913 (1992).

[19] D.M. Freik, V.M. Bojchuk, L.I. Mezhilovskaja, Neorganicheskie materialy 40(10), 1171 (2004).

[20] S. Bastien, N. Braidy, J. Phys. Chem. C 122(20), 11038 (2018).

[21] L. Liu, Y. Cheng, Z. Liu, M.N. Ha, Q. Guo, Z. Zhao, RSC Adv. 6(87), 83814 (2016).

[22] S.S. Lisnyak, A.V. Bitneva, V.O. Kotsyubinsky, I.P. Yaremy, G.V. Muhin, Physics and Chemistry of Solid State 1(3), 507 (2000).

[23] N. Ponpandian, P. Balaya, A. Narayanasamy, J. Phys.: Condens. Matter 14(12), 3221 (2002).

[24] K.J. Kim, T.Y. Koh, J. Park, J.Y. Park, J. Magn., 22(3), 360 (2017).

[25] S.T. Hugh, C. ONeill, A. Navrotsky, Am. Mineral. 68, 181 (1983).

[26] V.M. Talanov, Phys. Status Solidi B 106(1), 99 (1981).

[27] T. Kodama, Y. Kitayama, M. Tsuji, Y. Tamaura, J. Magn. Soc. Jpn. 20(2), 305 (1996).

\author{
В. Бойчук ${ }^{1}$, В. Коцюбинський ${ }^{1}$, Х. Бандура ${ }^{2}$, М. Годлевська ${ }^{1}$, \\ Б. Дзундза ${ }^{1}$, О. Хацевич ${ }^{1}$
}

\title{
Механізм енуклеації нікель-залізної шпінелі з водного розчину: кристалоквазіхімічний підхід
}

\author{
I ДВНЗ "Прикарпатський національний університет імені Василя Стефаника ", 76018, Івано-Франківськ, Украӥна, \\ vmbojchuk@gmail.com. \\ ${ }^{2}$ Івано-Франківський начіональний медичний університет, 76018 Івано-Франківськ, Украйна, \\ banduracristina@gmail.com.
}

\begin{abstract}
Запропоновано феноменологічну модель процесів формування нікель-залізного фериту зі структурою шпінелі на основі теорії часткових зарядів та аналізу процесів гідролізу і поліконденсації при взаємодії $\mathrm{Fe}^{3+}$-, $\mathrm{Fe}^{2+}$ - і $\mathrm{Ni}^{2+}$-гідроксокомплексів для різних значень рН реакційного середовища. Для перевірки отриманих результатів щодо закономірностей утворення гідроксокомплексів, використовували метод оптичної спектроскопії. Процеси нуклеації для нестехіометричної нікель-залізної шпінелі $\mathrm{Ni}_{x} \mathrm{Fe}_{3}$ ${ }_{x} O_{4-\delta}(\delta$ - киснева нестехіометрія) описані кристало-квазіхімічною методикою з врахуванням різних типів дефектів у шпінельній гратці. Для різних значень величини $\delta$ проведено аналіз зміни електропровідності та параметра гратки дефектної нікель-залізної шпінелі як функції вмісту $\mathrm{Ni}^{2+}$.

Ключові слова: дефектна нікель-залізна шпінель, гідрокомплекс, параметр гратки, оптична спектроскопія.
\end{abstract}

